\title{
Molecular relationship between the A and B chromosomes of Crepis capillaris
}

\author{
M. JAMILENA*, M. GARRIDO-RAMOS, C., RUIZ REJÓN \& M. RUIZ REJÓN \\ Departamento de Genética, Facultad de Ciencias, Universidad de Granada, Granada 18071, Spain
}

\begin{abstract}
The molecular structure of the B chromosome of Crepis capillaris has been analysed by DNA comparisons of plants with $2 \mathrm{~B}$ and $\mathrm{OB}$ chromosomes. No additional band, and no differences in the band intensity were detected in $2 \mathrm{~B}$ plants after digestion with 18 restriction enzymes. One hundred and five clones were obtained from $2 \mathrm{~B}$ plants using the phenol-emulsion reassociation technique in formamide (F-PERT). Only one (clone pCc21) gave rise to additional hybridization bands in the DNA from 2B plants, indicating that this sequence occurs both in $\mathrm{A}$ and $\mathrm{B}$ chromosomes. Clone pCc21 contains a 54-bp microsatellite sequence rich in CA dinucleotides, similar to those found in other eukaryotic genomes. We conclude that the B chromosome of $C$. capillaris carries no specific highly repetitive sequence, but consists of sequences also present in the A chromosomes. The possibility remains that the heterochromatic pericentromeric region of the $\mathrm{B}$ has a different organization with respect to standard heterochromatin.
\end{abstract}

Keywords: B chromosomes, Crepis capillaris, F-PERT, microsatellites.

\section{Introduction}

Little is known about the molecular structure and organization of B chromosomes. Studies in maize, rye and wheat have indicated that the DNA from plants with and without $\mathrm{B}$ chromosomes is indistinguishable in bouyant-density distribution in $\mathrm{CsCl}$ gradients and in reassociation kinetics (Chilton \& McCarthy, 1973; Dover, 19756; Rimpau \& Flavell, 1976). The use of genomic in situ hybridization (GISH) has confirmed that almost the whole rye B chromosome hybridizes with the DNA from plants without Bs (Tsujimoto \& Niwa, 1992). Similarly, in situ hybridization has also demonstrated that repeated DNA families occurring in the heterochromatin of A chromosomes of maize, Attractomorpha similis and Glossina, are also present in the heterochromatic C-bands of Bs in these species (Amos \& Dover, 1981; Peacock et al., 1981; Viotti et al., 1985; John et al., 1986), indicating that B chromosome DNA is very closely related to that of A chromosomes. However, specific repetitive DNA sequences have recently been isolated from the B chromosomes of Secale cereale (Sandery et al., 1990), Brachycome dichromosomatica (John et al., 1991) and Nasonia vitripennis (Eickbush et al., 1992).

*Correspondence: Department of Botany, School of Plant Sciences, University of Reading, Whiteknights, Reading RG6 2AS, U.K.
The B of Crepis capillaris $(2 n=6)$ is a metacentric iso-B which contains a large positive $\mathrm{C}$-band around the centromere (Maluszynska \& Schweizer, 1989). GISH experiments using $0 \mathrm{~B}$ and $2 \mathrm{~B}$ plant DNA as probes indicate that the DNA of the entire $\mathrm{B}$ of $C$. capillaris is highly homologous to A chromosome DNA (Jamilena et al., 1994). Nevertheless, we have isolated and cloned three repetitive DNA families that, although representing the majority of the A chromosome C-bands of $C$. capillaris, fail to hybridize with the B (Jamilena et al., 1994). Bearing in mind the partially heterochromatic nature of the $C$. capillaris B chromosome, we have used two different methods to analyse whether this B contains specific repeated DNA sequences:

1 by comparing the banding pattern of repetitive DNA sequences, after electrophoretically fractionating the restricted DNA from $0 \mathrm{~B}$ plants and $2 \mathrm{~B}$ plants;

2 by using the phenol-emulsion reassociation technique in formamide (F-PERT) in order to isolate and clone specific DNA sequences from the $\mathrm{B}$.

In both studies, we have found a high homology between $\mathrm{A}$ and $\mathrm{B}$ chromosome DNA, suggesting that Bs have not greatly diverged from A chromosomes at the molecular level. However, it is possible that the organization of the $\mathrm{B}$ heterochromatin has changed with respect to the standard heterochromatin. 


\section{Materials and methods}

Crepis capillaris seeds were generously provided by Prof. R. N. Jones. Plants of $C$. capillaris containing 0,1 , and $2 \mathrm{~B}$ chromosomes were identified by cytogenetic root-tip analysis.

\section{Restriction enzyme analysis, Southern and dot-blot hybridization and DNA sequencing}

The DNA was isolated from leaves of $0 \mathrm{~B}$ and $2 \mathrm{~B}$ plants as described in Dellaporta et al. (1983), purified further by several extractions with phenol and chloreform, and precipitated with ethanol. The DNA was digested with $5 \mathrm{U}$ of enzyme per $\mu \mathrm{g}$ of DNA for $8-16 \mathrm{~h}$. The resulting fragments were fractionated on 0.8 per cent agarose gel in $0.5 \times \mathrm{TBE}$ buffer $(1 \times \mathrm{TBE}$ is $0.09 \mathrm{M}$ Tris-borate, $0.002 \mathrm{M}$ EDTA) or in 3 per cent $\mathrm{Nu}$ Sieve GTG agarose gel in $1 \times$ TAE buffer $(1 \times$ TAE is $0.04 \mathrm{~m}$ Tris-acetate, $0.001 \mathrm{~m}$ EDTA). Southern blot and dot-blot hybridizations were performed as in Jamilena et al. (1993). For sequencing, the dideoxynucleotide-chain-terminator method of Sanger et al. (1977) and an automated laser fluorescent DNA sequencer (Pharmacia) were used.

\section{The phenol-emulsion reassociation technique in formamide (F-PERT)}

By sonication, $200 \mu \mathrm{g}$ of DNA from plants without Bs was sheared to a mean length of $600 \mathrm{bp}$ and combined with $1 \mu \mathrm{g}$ of $M b o I$-digested DNA from plants with two Bs. The DNA mixture $\left(50 \mu \mathrm{g} \mathrm{mL}^{-1}\right.$ final concentration) was denatured and allowed to reassociate in an aqueous phenol emulsion gently stirred for $48 \mathrm{~h}$, as proposed by Casna et al. (1986). After chloroform extraction and ethanol precipitation, the DNA was resuspended in TE buffer. Then $5 \mu \mathrm{g}$ of reassociated DNA was ligated into the BamH1 site of pUC19 and the ligation used to transform $E$. coli DH5 alpha competent cells.

\section{Results}

Two methods have been used to detect specific DNA sequences from the $\mathrm{B}$ chromosome of $C$. capillaris. Firstly, the DNAs from plants of $C$. capillaris with and without Bs were cleaved with 18 different restriction endonucleases: Dral, EcoRI, XbaI, BamH1, PvuII, $H i n$ dIII, MboI, HaeIII, RsaI, AluI, HpaII, MspI, NdeI, HindII, SacI, HinfI, Sau3A and DdeI. Each digest showed a specific banding pattern, indicating that the C. capillaris genome contains large amounts of repetitive DNA. In the 18 digests, however, no differences in the banding patterns and no differences in the intensity of the bands, were detected between the DNAs extracted from plants with and without Bs (Fig. 1).

Secondly, we used F-PERT to enrich the DNA from plants with two Bs for B-chromosome-specific sequences. The DNA from plants with two Bs was digested with $\mathrm{Mbol}$ and mixed with an excess of DNA from plants without Bs. It might be expected that the excess DNA from plants without Bs would hybridize with homologous sequences in the DNA from plants with two Bs. The specific DNA sequences from the B chromosomes, however, can hybridize only with themselves and therefore their reassociation would form fragments with two $\mathrm{Mbol}$ ends that could be ligated into the BamHI sites of a vector.

After cloning the reassociated DNA in the plasmid pUC19, we obtained 105 recombinant clones. To test for the presence of highly repetitive sequences specific to the Bs, denatured DNA from each clone was dotted on a nylon membrane and hybridized with labelled total DNA from plants with $2 \mathrm{Bs}$ and plants

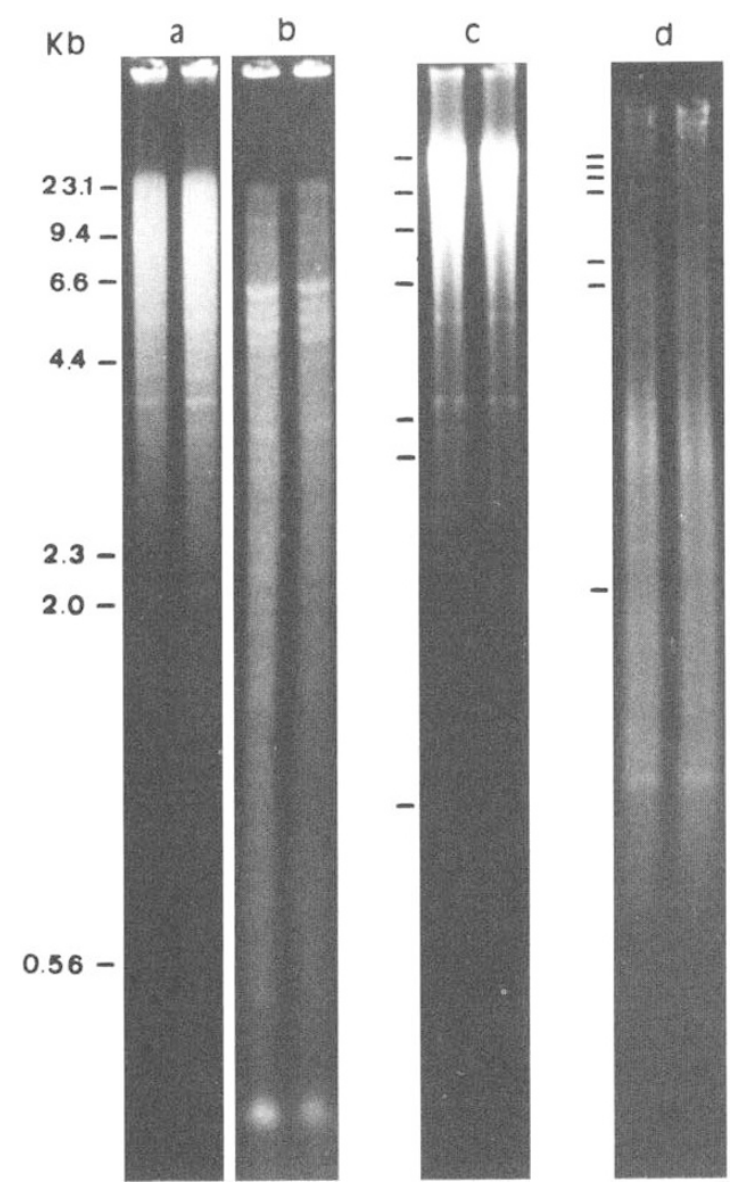

Fig. 1 Electrophoretic patterns of restricted DNA of $C$. capillaris plants with $2 \mathrm{Bs}$ (right) and without $\mathrm{Bs}$ (left). (a) EcoRI, (b) DraI, (c) XbaI, (d) MboI. 
Fig. 2 Southern-blot hybridizations of the pCc21 insert to restricted DNA of C. capillaris plants with two Bs (2) and without $\mathrm{Bs}(0)$. The DNA was digested with $E c o$ RI (Ec), SacI (Sc), HindIII (Hd), DraI (Dr) and MboI. Arrowheads indicate one EcoRI and one SacI band, present in the DNA from plants with Bs but absent from plants without Bs. In $M b o I$ digests, the DNA was treated with $0.5 \mathrm{U}$ per $\mu \mathrm{g}$ DNA for $15 \mathrm{~min}, 30$ $\mathrm{min}, 60 \mathrm{~min}, 90 \mathrm{~min}$ and $120 \mathrm{~min}$.
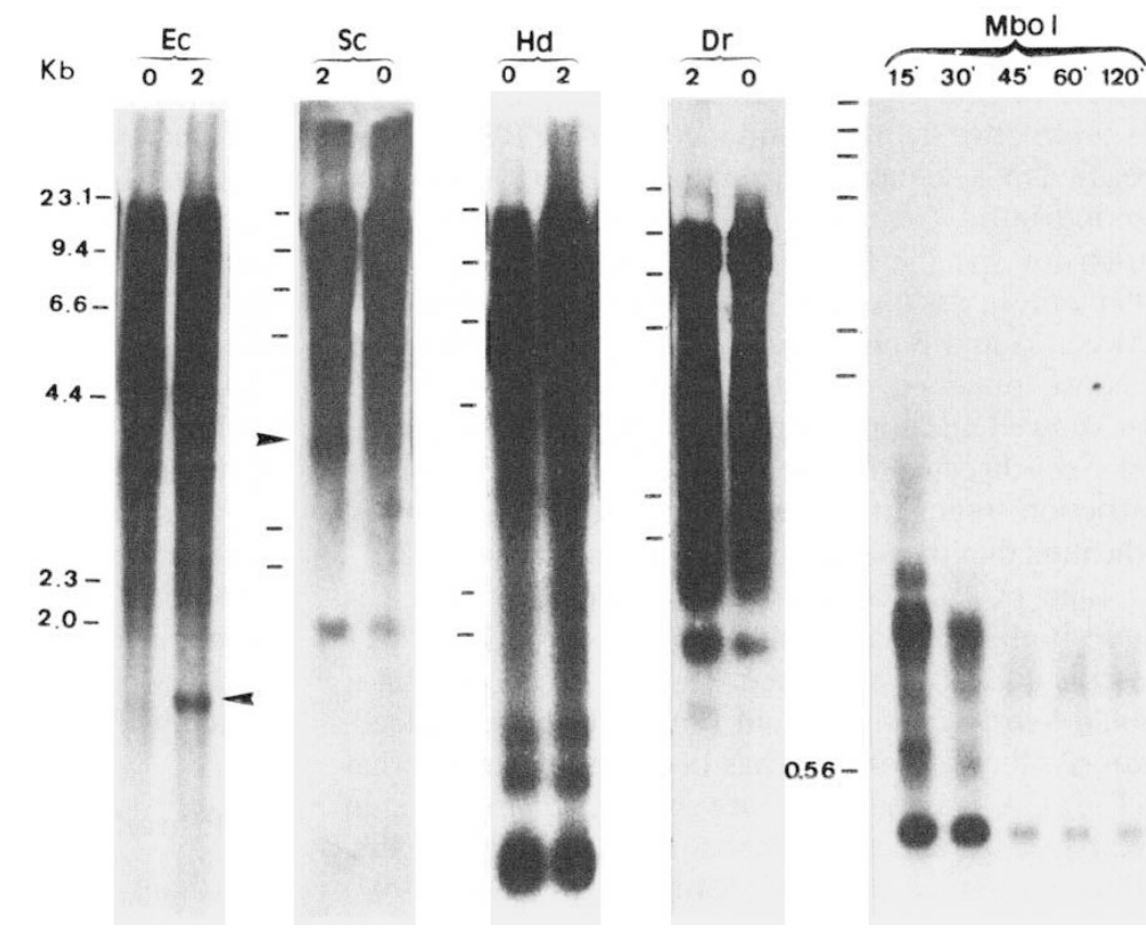

without Bs. However, no differences in hybridization were detected between $0 \mathrm{~B}$ and $2 \mathrm{~B}$ plants.

In addition, blots of EcoRI-, DraI- and HindIIIdigested DNA from $0 \mathrm{~B}$ and $2 \mathrm{~B}$ plants were hybridized with labelled DNA from each of the clones. The same hybridization patterns were given by 104 clones regardless of the presence or absence of Bs. The clone $\mathrm{pCc} 21$, however, showed a number of additional bands in SacI- and EcoRI- digested DNA from 2B plants (Fig. 2). In the 16 individuals analysed (eight $2 \mathrm{~B}$ and eight $0 \mathrm{~B}$ ), the additional EcoRI and SacI restriction fragments appeared only in the DNA from plants with Bs. By contrast, DraI, MboI and HindIII did not distinguish the two groups (Fig. 2). Thus failure to detect differences between $2 \mathrm{~B}$ and $\mathrm{OB}$ plants when using the remaining 104 clones suggests either that the appropriate restriction enzyme has not been used or that strong homology exists between $\mathrm{A}$ and $\mathrm{B}$ chromosome DNA sequences.

The plasmid pCc21 contained an insert of $54 \mathrm{bp}$ rich in the CA dinucleotide (gatctaacacacgcagtacacacacacaaacacacagacacacatagaaaacgt). Hybridization of the pCc21 insert to HindIII-, EcoRI-, DraI- and SacIdigested DNA from $0 \mathrm{~B}$ and $2 \mathrm{~B}$ plants gave rise to a smear, but also to bands whose length varied between digestions (Fig. 2). Since none of these enzymes has cleavage sites in the $\mathrm{pCc} 21$ insert, this hybridization pattern indicates that CA-rich sequences are dispersed throughout the $C$. capillaris genome. In addition, when DNA from plants with or without Bs was digested for varying lengths of time with $\mathrm{MboI}$ (the enzyme used to generate the insert of $\mathrm{pCc} 21$ ), and probed with the pCc21 insert, hybridizing fragments showed a decrease in size and intensity with an increase in digestion (Fig. 2). This observation suggests that $\mathrm{CA}$-rich sequences are very short and an enzyme with a 4-bp cleavage site such as $\mathrm{MboI}$ is able to generate fragments so small that they are lost from the gel during electrophoresis and so cannot be detected.

\section{Discussion}

We have analysed the DNA from $C$. capillaris plants with and without $\mathrm{B}$ chromosomes. Comparing the electrophoretic patterns between the DNAs of $2 \mathrm{~B}$ and $0 \mathrm{~B}$ plants digested with 18 restriction enzymes, we have detected no differences. Each enzyme produced a number of different bands which undoubtedly contain repetitive DNA sequences (Flavell, 1982). However, no additional bands and no differences in the intensity of the bands were observed in plants with Bs. These data may indicate that highly repetitive DNA sequences on $\mathrm{B}$ chromosomes are similar to those on A chromosomes. However, it is possible that we have not used the appropriate restriction enzymes to reveal Bspecific repeated sequences. Lima de Faria et al. (1983) observed that the banding patterns generated from rye DNA of plants with and without Bs by four enzymes were similar. Sandery et al. (1990), however, later found a DraI band of $1.1 \mathrm{~kb}$ specific to DNA from rye plants with B chromosomes. 
In the case of $C$. capillaris, however, the second hypothesis is less probable since we have used a large number of restriction enzymes. In addition, the use of the subtractive hybridization method F-PERT to clone specific DNA sequences from the $\mathrm{B}$ of $C$. capillaris was also unfruitful. Given the potential of this technique to enrich for specific B chromosome DNA (John et al., 1991), these results may indicate a close relationship between $\mathrm{A}$ and $\mathrm{B}$ chromosome DNA sequences. However, we obtained one clone ( $\mathrm{pCc} 21$ ) from F-PERT that showed additonal restriction fragments in EcoRIand SacI-digested DNA from plants with Bs. These restriction fragments were confined to plants with Bs, indicating that they arose from $\mathrm{B}$ chromosome DNA.

Clone pCc21 contains a DNA sequence which is found both in $\mathrm{A}$ and $\mathrm{B}$ chromosomes. As the $\mathrm{pCc} 21$ insert is a CA-rich sequence, it is not surprising that it should hybridize with A and B chromosomes. Indeed, using synthetic probes, it has been demonstrated that $(\mathrm{GT}) n /(\mathrm{CA}) n$ sequences are widely distributed in eukaryotic genomes (Hamada et al., 1982; Rogers, 1983; Huijser et al., 1987; Condit \& Hubell, 1991; Lönn et al., 1992). These simple repetitive DNA sequences, or microsatellites, are tandemly organized in short clusters which are themselves randomly dispersed in the genome (Hamada et al., 1982). The CArich insert of $\mathrm{pCc} 21$ shows those characteristics. As in other plants (Condit \& Hubbell, 1991), these (CA)n sequences are organized in short clusters as suggested by partial digestions of $C$. capillaris DNA with $M b o \mathrm{I}$. In addition, the smear-hybridization pattern of $\mathrm{pCc} 21$ also indicates that these regions are randomly dispersed throughout the genome. On the other hand, bands appearing in Southern blot hybridization with $\mathrm{pCc} 21$, some of which are B-associated, suggest that several (CA) $n$ sequences occur within a large dispersed repetitive sequence. Thus, the $\mathrm{B}$ chromosome-specific bands hybridizing with $\mathrm{pCc} 21$ may indicate that the length and/or the environment of (CA) $n$ clusters vary between $\mathrm{A}$ and $\mathrm{B}$ chromosomes. On the other hand, the pCc21 insert may be part of a large dispersed repetitive sequence which varies between $\mathrm{A}$ and $\mathrm{B}$ chromosomes.

The data thus indicate that the molecular structure of the $C$. capillaris $\mathrm{B}$ chromosome is closely related to that of the A chromosomes, with no specific repetitive sequences. These data confirm our previous results from GISH, which demonstrated that the entire B chromosome hybridizes with total DNA from plants without Bs (Jamilena et al., 1994). The pericentromeric heterochromatin of $C$. capillaris $\mathrm{B}$ chromosomes therefore may be formed by one or several repetitive families also present in the A chromosomes. However, none of the three repetitive DNA sequences which make up the majority of the heterochromatin of $C$. capillaris A chromosomes has been found in the B (Jamilena et al., 1994). Thus it is likely that the chromosome organization of the pericentromeric region of this $\mathrm{B}$, although heterochromatic, has a specific chromosome organization not particularly enriched in highly repetitive DNA sequences. Jones \& Rees (1982) have also suggested the possibility that chromosome organization of Bs may differ from that of As. Compared with other heterochromatic regions (John, 1988), B heterochromatin in C. capillaris is distinct. The DNA density in the B is lower than in the A chromosomes (Maluszynska, 1990). Although heterochromatin is normally associated with highly repetitive sequences, this association is not universal: some heterochromatic regions contain no repeated DNA, while some highly repeated sequences are associated with euchromatic regions (John, 1988).

\section{Acknowledgements}

We thank Prof. R. N. Jones for providing us with the Crepis capillaris seeds used in this work and Prof. J. S. Parker for critical reading of the manuscript. This work was supported by a grant from the Spanish CICYT (No. PB90-0847), and by the Plan Andaluz de Investigación (Group No. 3186). We also thank David Nesbitt for improving the English.

\section{References}

AMOS, A. AND DOVER, G. 1981. The distribution of repetitive DNAs between regular and supernumerary chromosomes in species of Glossina (Tsetse): a two-step process in the origin of supernumeraries. Chromosoma, 81, 673-690.

CASNA, N. J., NOVACK, D. F., HSU, M. T. AND FORD, J. P. 1986. Genomic analysis. II. Isolation of high molecular weight heteroduplex DNA following differential methylase protection and formamide-PERT hybridization. Nucleic Acids Res., 14, 7285-7303.

CHILTON, M. D. AND McCARTHY, B. J. 1973. DNA from maize with and without $\mathrm{B}$ chromosomes: a comparative study. Genetics, 74, 605-614.

CONDIT, R. AND HUBBELl, S. P. 1991. Abundance and DNA sequence of two-base repeat regions in tropical tree genomes. Genome, 34, 66-71.

DELLAPORTA, S. L., WOOD, J. AND HICKS, J. B. 1983. A plant DNA minipreparation: version II. Plant Mol. Biol. Rep., 1, 19-21.

DOVER, G. A. 1976. Observations on the repeated sequence DNA of " $A$ " and " $B$ " chromosomes of genotypes in the Triticinae with contrasting patterns of meiotic chromosome pairing. Chromosomes Today, 5, 131-145.

EICKBUSH, D. G., ElCKBUSH, T. H. AND WERREN, J. H. 1992. Molecular characterization of repetitive DNA sequences from a B chromosome. Chromosoma, 101, 575-583. 
FLAVELL, R. B. 1982. Chromosomal DNA sequences and their organization. In: Parthier, B. and Boulter, D. (eds) Nucleic Acids and Proteins in Plants, pp. 46-74. Springer, Berlin.

hamada, H., PETRINO, M. G. AND KakUnaGa, T. 1982. A novel repeated element with $Z$-DNA forming potential is widely found in evolutionarily diverse eukaryotic genomes. Proc. Natl. Acad. Sci. U.S.A., 79, 6465-6469.

HUIJSER, P., HENNING, W. AND DIJKHOF, R. 1987. Poly (dC-dA/dGdT) repeats in the Drosophila genome. Chromosoma, 95, 209-215.

JAMILENA, M., RUIZ REJON, C. AND RUIZ REJON, M. 1993. Repetitive DNA sequence families in Crepis capillaris. Chromosoma, 102, 272-278.

JAMILENA, M., RUIZ REJON, C. AND RUIZ REJÓN, M. 1994. A molecular analysis of the origin of the Crepis capillaris $\mathrm{B}$ chromosome. J. Cell Sci., 107, 703-708.

JOHN, B. 1988. The biology of heterochromatin. In: Verma, R. S. (ed.) Heterochromatin. Molecular and Structural Aspects, pp. 1-147. Cambridge University Press, Cambridge.

JoHN, B., APPELS, R. AND CONTRERAS, N. 1986. Population cytogenetics of Atractomorpha similis. II. Molecular characterization of the distal $\mathrm{C}$ band polymorphisms. Chromosoma, 94, 45-58.

JOHN, U. P., LEACH, C. R. AND TIMMIS, J. N. 1991. A sequence specific to $\mathrm{B}$ chromosomes of Brachycome dichromosomatica. Genome, 34, 739-744.

JONES, R. N. AND REES, H. 1982. B Chromosomes, Academic Press, London.

LIMA DE FARIA, A., ESSEN-MOLLER, J., MÜNTZING, A., GRANDSTROM, H., OLSSON, E. AND ISAKSSON, M. 1983. Comparison of DNA cleavage in rye with and without B chromosomes. Hereditas, 99, 203-208.
LÖNN, M., TEGELSTRÖM, H. AND PRENTICE, H. C. 1992. The synthetic (TG) $n$ polydinucleotide: a probe for gene flow and paternity studies in wild plant populations? Nucleic Acids Res., 20, 1153.

MALUSZYNSKA, J. 1990. B chromosomes of Crepis capillaris (L.) Waller. In vivo and in vitro. Universytet Slaski, Katowice.

MALUSZYNSKA, J. AND SCHWEIZER, D. 1989. Ribosomal RNA genes in B chromosomes of Crepis capillaris detected by non-radioactive in situ hybridization. Heredity, 62, 59-65.

PEACOCK, W. J., DENNIS, E. S., RHOADES, M. M. AND PRYOR, A. J. 1981. Highly repeated DNA sequence limited to knob heterochromatin in maize. Proc. Natl. Acad. Sci. U.S.A., 78, 4490-4494.

RIMPAU, J. AND FLAVELL, R. B. 1976. The repeated sequence DNA of B chromosomes of rye. Chromosomes Today, $\mathbf{5}$, 147-157.

ROGERs, J. 1983. CACA sequences - the ends and the means? Nature, 305, 101-102.

SANDERY, M. J., FORSTER, J. W., BLUNDEN, R. AND JONES, R. N. 1990. Identification of a family of repeated sequences on the rye B chromosome. Genome, 33, 908-913.

SANGER, F., NICKLEN, S. AND COULSON, A. R. 1977. DNA sequencing with chain terminating inhibitors. Proc. Natl. Acad. Sci. U.S.A., 74, 5463-5467.

Tsujimoto, H. AND NIWA, K. 1992. DNA structure of the B chromosome of rye revealed in in situ hybridization using repetitive sequences. Jap. J. Genet., 67, 233-241.

VIOTTI, A., PRIVITERA, E., SALA, E. AND POGNA, N. 1985. Distribution and clustering of two highly repeated sequences in the A and B chromosomes of maize. Theor. Appl. Genet., 70, 234-239. 